\title{
The Impact of Seaweed Farming on Marital and Reproductive Role Satisfaction
}

\author{
Evaline L. Apura \\ Iloilo Science and Technology University, Barotac Nuevo Campus, Jalaud, Btac. Nuevo, Iloilo \\ apuraevaline@gmail.com
}

\begin{abstract}
Seaweed farming has materialized as the most pertinent livelihood strategy among coastal areas. This livelihood is mostly participated by couples to augment their income for family's subsistence. This descriptive-correlational research was conducted to determine the impact of seaweeds farming to the marital relationship satisfaction and reproductive role satisfaction of the seaweed farmers of Brgy. Tiabas, San Dionesio, Iloilo. Checklist questionnaire made by the researcher adapted from Marital Satisfaction Inventory and reproductive role questionnaire were used during the data collection. The collection of data was from October 2016 to March 2017. The findings showed very high marital relationship satisfaction when the respondents were classified according to sex, years of marriage, family income and family size. However, the findings revealed low reproductive role satisfaction when the respondents were classified according to sex, years of marriage, family income and family size. No significant differences among variables in the study. Thus, it was concluded that appreciation of responsible parenthood and gender equality should be delivered to the farmers for harmonious relationship in the households.
\end{abstract}

Keywords: "Seaweeds", "Marital Relationship Satisfaction", "Reproductive Role Satisfaction".

\section{INTRODUCTION}

Seaweed is harvested throughout the world as a food source as well as an export commodity for the production of agar and carrageenan products. In the Philippines, seaweed exports increased almost twenty fold from 675 MT in 1967 to 13,191 MT in 1980 (Trono 1990) and it is usually done by couples.

According to Valderama (2012), seaweed farming has emerged as most prevalent livelihood strategy among family living along the shore. In Barangay Tiabas, municipality of San. Dionesio, majority of couples are engaging in seaweed farming endeavors. It is normally maintained by family that serves as their bread and butter. They view the said farming as means of livelihood which supplies their basic needs and educational support of their children. For the marginalized community of Brgy. Tiabas, seaweed farming has brought substantial socioeconomic benefits to their family. The activity has generated employment to and uplifted the socioeconomic status of tens of thousands of coastal families in the country (Hurtado, 2013).
Marital satisfaction of couples engaging in seaweed farming was less taken into consideration by most researcher. The income received, household division of work, time spent by the couples for children and their lives as husband and wife are oftentimes led to sacrifice as they both work in seaweed farming. It is in this scenario that the researcher has thought of determining the impact of seaweed farming to the marital satisfaction of couples.

\subsection{Theoretical Framework}

This study was anchored to Dynamic Theory of Marital Satisfaction. According to Li and Fung (2011), marriage is more voluntary and is symbolized by the couple's love for each other and desire to be together. Their marital satisfaction is the main factor that influences the dynamic goal theory of marital satisfaction, which looks at the marital quality and emotional aspect of the marriage (Li \& Fung, 2011). The theory argues that marital goals are the core foundation of marriage and need to be achieved reach marital satisfaction. These are personal growth, companionship goal and instrumental goal. Instrumental goals are often 
applied as a division of household effort and responsibilities.

Moreover, this study is also linked to social exchange theory, that individuals in relationship are motivated by goodness of outcomes they are expected to bring (Blau, 1964). Marital partners yield goodness of outcomes based on rewards and costs, but each partner must value the mutual activity above a comparison level in order for relational solidarity to be sustained.

Marital couples who receive favorable reward/cost outcomes from each other- the proportion of rewards and costs are distributed in a fair ratio to each other-are more likely to be satisfied with their marriage (Homans, 1974). Couples satisfied with their marriage are less likely to dissolve the marriage through divorce or separation (Levinger, 1979).

On this note, marital satisfaction of couple seaweed farmers needs to ensure their love and mutual support to each other. These will enable them to maintain and manage their family and livelihood.

\subsubsection{Conceptual Framework}

The conceptual framework of this study is presented in the schematic diagram below:

\begin{tabular}{|c|c|c|}
\hline $\begin{array}{l}\text { Independent } \\
\text { Variables }\end{array}$ & $\begin{array}{l}\text { Intervening } \\
\text { Variable }\end{array}$ & $\begin{array}{l}\text { Dependent } \\
\text { Variables }\end{array}$ \\
\hline Sex & & Marital \\
\hline Age & Seaweed & $\begin{array}{l}\text { Relationship } \\
\text { Satisfaction }\end{array}$ \\
\hline Years of Marriage & Farming & \\
\hline $\begin{array}{l}\text { Family Income } \\
\text { Time Spent } \\
\text { Family Size }\end{array}$ & & $\begin{array}{c}\text { Reproductive } \\
\text { Roles } \\
\text { Satisfaction }\end{array}$ \\
\hline
\end{tabular}

Figure 1. Schematic diagram showing the relationship between variables.

Figure 1 shows the relationship of the independent variables and the dependent variable. The independent variables are factors such as course, and sex. It was hypothesized in this study that the said independent variables were factors that affect marital and reproductive role satisfaction of married-seaweed farmers, the dependent variable of this study.

\subsection{Statement of the Problem}

This research study aimed to determine the impact of seaweed farming to the marital and reproductive role satisfaction among married couples of Brgy. Tiabas, San
Dionesio, Iloilo seaweed farmers. Specifically, this research sought to answer the following questions:

What is the level impact of seaweed farming on marital satisfaction among married couple-farmers of Brgy. Tiabas, San Dionesio in terms of sex, age, time spent in seaweed farming, family income, length of marriage and family size.

Is there significant difference in the level of impact of seaweed farming on the marital satisfaction among married couple-famers of Brgy. Tiabas, San Dionesio in terms of sex, age, time spent in seaweed farming, family income, length of marriage and family size.

What is the level of impact of seaweed farming on reproductive role among married couple-farmers of Brgy. Tiabas, San Dionesio in terms of sex, age, time spent in seaweed farming, family income, length of marriage and family size. Is there significant difference in the level of impact of seaweed farming on the reproductive role among married couple-famers of Brgy. Tiabas, San Dionesio in terms of sex, age, time spent in seaweed farming, family income, length of marriage and family size.

\subsection{Hypotheses}

Based on the preceding questions, the following null hypotheses were advanced: Ho1. There is no significant difference in the level of impact of seaweed farming on the marital satisfaction among married couple-famers of Brgy. Tiabas, San Dionesio in terms of sex, time spent in seaweed farming, family income, length of marriage and family size. Ho2. There is no difference in the level of impact of seaweed farming on the reproductive role among married couple-famers of Brgy. Tiabas, San Dionesio in terms of sex, time spent in seaweed farming, family income, length of marriage and family size.

\subsection{Significance of the study}

The findings of this study are beneficial to the following: Married couples. Results of this study is a significant help among married couples to achieve a well satisfied married life. It will provide them ideas and learning on how to grow personally, maintain companionship and instrumentally part of satisfied marriage. Seaweed Farmers. The results of this can provide check and balance among seaweed farmers on their seaweed farming and reproductive roles to achieve marital satisfaction. Since marital satisfaction is very vital among spouses. Community. It is one of the stakeholders of the ISAT $U$, where learning of knowledge, skills and values are earned. The result of the study will be share to them through conduct of seminar and orientation. This knowledge can improve their marital relationship satisfaction and benefit the 
community in many ways. LGU. It has been said that a happy home means a happy community. Seaweeds farmer couples with high marital satisfaction are economically productive couples. This in turns will yield more income not only to family but the local economy. Consequently, the result of this study ushers local projects and programs geared on seaweed farming that benefit both the local economy and marital and reproductive role satisfaction. HEIs. Findings can contribute to development of technology, skills and knowledge for the ISAT $U$ can patent and extend. Researchers. Other researches can make use of the study to go similar studies concerning marital satisfaction, division of labor and seaweed farming.

\subsection{Definition of Terms}

The following terms are defined to provide clarity of usage. The definitions section of this study help the reader understand the terms used in his study.

Marital Satisfaction. Is a mental state that reflects the perceived benefits and costs of marriage to a particular person? The more costs a marriage partner inflicts on a person, the less satisfied one generally is with themarriage and with the marriage partner. https://www.google.com/search?q=marital+satisfaction \&rlz=1C1RUCY enPH854\&oq=marital+satisfaction+ $\underline{\text { \&aqs }=\text { chrome. } .69 \mathrm{i} 57.6645 \mathrm{j} 0 \mathrm{j} 8 \& \text { sourceid }=\text { chrome } \& \mathrm{ie}=}$ $\underline{\mathrm{UTF}-8}$

In this study, marital satisfaction is denoted as contentment of married couples who are seaweed farmers of Brgy. Tiabas, San Dionesio.

Seaweed farming . Seaweed farming is the practice of cultivating and harvesting seaweed. In its simplest form, it consists of the management of naturally found batches. In its most advanced form, it consists of fully controlling the life cycle of the algae. https://en.wikipedia.org/wiki/Seaweed farming

In this study, it referred to the livelihood of residents of Brgy. Tiabas, San Dionesio, especially of the married couples.

Reproductive role. A reproductive role or domestic role refers to all activities necessary for the maintenance and survival of human life.

In this study, reproductive role satisfaction pertained to equal distribution of household chores or task which makes each spouse contented.

\subsection{Scope and Limitation of the study}

This descriptive-correlational research design will determine the marital satisfaction and reproductive role satisfaction of the seaweed farmers of Brgy. Tiabas, San Dionesio, Iloilo, Philippines. This was done among the 76 married couples who are seaweed farmers. The number represent the $90 \%$ of the total population of the said group and place.

The research instrument was adapted from marital satisfaction questionnaires, which was revised to fit the purpose of the study. Data gathered were tallied, tabulated, analyzed and interpreted using frequency count, percentage, mean, standard deviation, t-test, ANNOVA, and Pearson r set at .05 level of significance.

\section{LITERATURE REVIEW}

\section{Seaweed Farming}

In study of Valderama (2012), seaweed farming has positive to the coastal communities. The FAO study also explains how the economic fortunes of many villages have been transformed by seaweed farming. Many of these communities routinely lived at or below poverty levels prior to engaging in aquaculture; with their income earned from the sale of seaweeds, many farmers have experienced substantial improvements in their standards of living as they are able to send their children to school, introduce improvements to their dwellings, enhance their diets, increase their purchasing power of material goods, etc. Seaweed farming had a remarkable positive effect on the socioeconomic status of female farmers as it allows them to engage in an income-earning activity that can be undertaken without neglecting traditional household chores.

The link between spousal agreement on employment decisions and increased marital satisfaction is also confirmed in the work by Helms et al. (2010). Findings indicated that couples who had a shared sense of family earnings and family responsibilities reported the highest levels of marital satisfaction.

In addition, Helms et al., (2010) provides insights into the marital satisfaction for dual earner couples. By using the categories suggested by Hood (1986), they found that marital satisfaction is amplified when both spouses are co-provider perspectives that recognize the contributions of wives' employment to family earnings. Couples in coprovider group reported the greatest marital satisfaction "for whom partners' attitudes about breadwinning matched their own employment behavior and one another's attitudes."

\subsection{Role of Marriage}

Despite the fact that marriage is a less dominant social structure in the twenty-first century than any other time in United States history, a majority of individuals still become married and a large number of those who marry intend to be steady and satisfied in their marital relationships (Cherlin, 2005). Further, Cherlin (2005) says that as marriage has changed over the decades, being married has become less about safeguarding one's role as 
an adult and more about a milestone representing successful self-development. Furthermore, ingrained in the transition of marriage is the notion that becoming married is an avenue to receive individual rewards such as support and greater financial stability. Thus, if individual rewards are not attained, a marriage is more likely to end. However, if the institution of marriage has become more customized, to what extent do spouses still depend on their partner to feel satisfied.

Beach and colleagues (1993) examined the extent to which individuals turn to their spouse for social support and attribute interpersonal stress to their partner. The authors posited that even though a relationship between marital satisfaction and depression exists, it may be moderated by the relationships that individuals have with other family members or co-workers. Further, if satisfaction does not significantly reflect the nature of the support and negative interactions within a marriage, or if a majority of social support and interpersonal stress are found outside of the marital relationship, the strength of the linkage between marital satisfaction and depression may not be as significant as once thought (Beach et al., 1993). The data showed that an individual's spouse was reported to be the most relevant source of support measured by active listening, confiding, and advice seeking. As expected, spouses were reported to be the most significant source when interpersonal stress was reported. Specifically, spouses were indicated to be the most significant source of criticism, misunderstanding, and arguments (Beach et al., 1993). Thus, this study conducted by Beach and colleagues (1993) may lend further support to the impact of the spouse on an individual's psychological well-being.

\subsection{Marital satisfaction and gender.}

Historically, the advantages to becoming married have been associated with increased social support, social involvement, economic advantages, and avoidance of the stigma of remaining single (Ross, 1991). However, as societal norms change, remaining unmarried is no longer considered to be as stigmatized (Cherlin, 2005). Although society may be progressing in its acceptance of women who choose to remain single, there are subcultures to which an individual may belong in which it may not be any more acceptable to remain unmarried. Individuals, especially women, may still encounter the pressure to be married from their family, religious community, or ethnic culture.

Faulkner and colleagues (2005) conducted a study examining the relationship between gender-related predictors of husbands' and wives' marital satisfaction and conflict. The researchers utilized longitudinal data of couples in first marriages from the National Survey of Families and Households. Using multiple regression analysis to predict models of change at Time 2 for marital satisfaction and marital conflict and probability weights to allow for the generalization to populations, the results of their study demonstrated wives' self-report of depression and their husbands' self-report of depression resulted in increased levels of marital conflict over time. Additionally, a negative change in the well-being of wives showed an increase in marital conflict over a fiveyear period (Faulkner et al., 2005). Wives' report of marital conflict also associated with poor psychological well-being of their husbands. Higher levels of depression for both husbands and wives were indicative of a decrease in husband's marital satisfaction as measured over time (Faulkner et al., 2005). Wives who reported experiencing depressive symptoms also reported experiencing a decrease in marital satisfaction. On the other hand, when wives reported positive well-being, they also reported an increase in marital satisfaction over time (Faulkner et al., 2005).

Additionally, Faulkner and colleagues (2005) suggest that wives may be socialized to attend not only to their own interpersonal functioning but the functioning of their marital relationship, and their interpretations or evaluations of the relationship may be more predictive of marital quality than their husband's appraisal of marital quality. Therefore, Faulkner and colleagues recommend that therapists may need to specifically address gender roles to help educate both genders about role differences, expectations, and their relationship to marital satisfaction.

\subsection{Factors contributing to Satisfaction in Marriage}

There have been several studies that have looked retrospectively at long lasting marriages in order to determine the reasons for their longevity Robinson and Bloton (1993) found that the key characteristics identified by such couples included: intimacy balanced with autonomy, commitment, communication, similar religious orientation, and congruent perceptions of the relationship.

In the study of Sokloski (1995), he found that marital satisfaction was directly related to the length of marriage, inversely related to number of children and number of child-rearing problems. He also found that these variables were more strongly correlated with satisfaction for wives that for husbands. Thus, gender differences related to marital satisfaction appear to be an important consideration.

\subsection{Gender roles and Marital Satisfaction}

Closely associated with the idea of marital satisfaction, gender, and employment status are a couple's gender roles. Gender role ideology explains the beliefs and attitudes one has about the acceptable roles of women and men (McElwain, Korabik, \& Rosin, 2005). Gender-role ideology is based on a theoretical continuum 
from a traditional perspective (a man's primary responsibility is to financially provide; a woman's primary responsibility is to care for the home and family) to an egalitarian perspective ( a man and woman are equally responsible for work, home and family responsibilities).

Some studies suggest that the decision to be a single earner or dual earner household closely intersects with couples' beliefs related to gender roles. Shared

\section{METHODOLOGY}

This chapter includes the research design, respondents of the study, data gathering instruments, data gathering procedure and data processing technique.

\subsection{Research Design}

This study utilized a descriptive-quantitative research design to determine and examine the impact of seaweed farming to the marital and reproductive role satisfaction among married couple- seaweed farmers. Descriptivequantitative research design (Cristobal, Jr. \& Cristobal, 2013) revealed the systematic structure, in variance, that is not only for the cases that were studied, but the entire group. Furthermore, its purpose is to portray a population that has been chosen because of some specific characteristics.

\subsection{Environment}

Barangay Tiabas is one of the barangays of the municipality of San Dionesio, in the province of Iloilo. Its population as determined by 2018 Census was 2,150 . This represented $5.41 \%$ of the total population of San Dionesio. Tiabas is situated at approximately 11, 2907, 123.0948, in the island of Panay. It is also a coastal barangay in which major livelihood of the residents came from its coastal produces. Likewise, it is gifted with agricultural land at the foot of the mountain on the opposite side of the coast.

\subsection{Respondents of the study}

The respondents of the study were the seventy six married couple-seaweed farmers of Barangay Tiabas, San Dionesio, Iloilo, Philippines. They were purposively identified and chosen as respondents of the study.

Table 1. Profile of the respondents

\begin{tabular}{|c|c|c|c|}
\hline Category & & $\mathrm{f}$ & $\%$ \\
\hline \multicolumn{4}{|c|}{ A. Entire group } \\
\hline \multicolumn{4}{|c|}{ B. Sex } \\
\hline & Male & 32 & 42 \\
\hline & Female & 44 & 58 \\
\hline \multicolumn{4}{|c|}{ C. Length of Marriage } \\
\hline & $1-15$ yrs. & 27 & 36 \\
\hline & $16-30 \mathrm{yrs}$. & 32 & 42 \\
\hline
\end{tabular}

\begin{tabular}{|c|c|c|c|}
\hline & $31-45$ yrs. & 17 & 22 \\
\hline \multirow[t]{3}{*}{ D. } & Age & & \\
\hline & Young & 7 & 9 \\
\hline & Old & 69 & 91 \\
\hline \multirow[t]{3}{*}{ E. } & Family Size & & \\
\hline & $5 \&$ below & 33 & 43 \\
\hline & $6 \&$ above & 43 & 57 \\
\hline \multirow[t]{3}{*}{ F. } & $\begin{array}{l}\text { Time spent on } \\
\text { Seaweed farming }\end{array}$ & & \\
\hline & $1-5 \mathrm{hrs} . /$ day & 57 & 75 \\
\hline & 6-10 hrs./day & 19 & 25 \\
\hline \multirow[t]{3}{*}{ G. } & Family income & & \\
\hline & Php.1,000- Php.5,000 & $0 \quad 53$ & 70 \\
\hline & Php.6,000-Php.10,00 & $00 \quad 23$ & 30 \\
\hline
\end{tabular}

\subsection{Data Gathering Instrument}

The researcher used the instrument composed of four parts: Part I- Personal profile of the respondents, Part IIan adapted marital satisfaction inventory, Part III- a researcher-made questionnaire on the reproductive role of married couple-seaweed farmers.

The instrument was submitted to three experts for content validation. After the approval, the questionnaire was reproduced and conducted personally.

For the level marital satisfaction, the following response with numerical weight was used:

$\begin{array}{lcl}\text { Response } & \text { Weight } & \text { Interpretations } \\ \text { Always } & 5 & \text { Very high } \\ \text { Often } & 4 & \text { High } \\ \text { Sometimes } & 3 & \text { Moderate } \\ \text { Rarely } & 2 & \text { Low } \\ \text { Never } & 1 & \text { Very Low }\end{array}$

In interpreting the level marital satisfaction the weighted scores the following scales were used with an interval of 27 .

$\begin{array}{lc}\text { Scale } & \text { Interpretations } \\ 108.01-135.00 & \text { Very High } \\ 81.01-108.00 & \text { High } \\ 54.01-81.00 & \text { Moderate } \\ 27.01-54.00 & \text { Low } \\ 1.00-27.00 & \text { Very low }\end{array}$

For the level of reproductive role satisfaction, the following response with numerical weight to each were used:

$\begin{array}{lcc}\text { Response } & \text { Weight } & \text { Interpretations } \\ \text { Always } & 5 & \text { Very high } \\ \text { Often } & 4 & \text { High } \\ \text { Sometimes } & 3 & \text { Moderate } \\ \text { Rarely } & 2 & \text { Low } \\ \text { Never } & 1 & \text { Very Low }\end{array}$


In interpreting the weighted scores of level of reproductive role satisfaction the following scores with an interval of 15 were used:

$\begin{array}{lc}\text { Scale } & \text { Interpretations } \\ 36.01-45.00 & \text { Very high } \\ 27.01-36.00 & \text { High } \\ 18.01-27.00 & \text { Moderate } \\ 09.01-18.00 & \text { Low } \\ 01.00-9.00 & \text { Very low }\end{array}$

\subsection{Data Gathering Procedure}

After the questionnaire had been validated and tested for reliability, the researcher secured a permit to conduct from the Local Government Unit of San Dionesio and Barangay Tiabas. Copies of questionnaire were reproduced and personally conducted to the seventy six respondents. After the retrieval of the copies, the respondents were assured that their responses will be treated with confidentiality.

\subsection{Data Processing Technique}

The data were tallied, tabulated, analysed and interpreted.

Frequency count, mean and standard deviation were used in determining the level of marital and reproductive role satisfaction of married couple-seaweed farmers when the respondents were taken as a whole and when classified in terms of sex, age, time spent in seaweed farming, family income, length of marriage and family size.

Meanwhile, mean, standard deviation, t-test for independent sample and One way Analysis of Variance (ANOVA) set at .05 level of significance were used to test the significant difference in marital and reproductive role satisfaction when the respondents were classified in terms of age, sex, time spent in seaweed farming, family income, length of marriage and family size.

Pearson $r$ was also used to determine and measure correlation of impact level to marital and reproduction role satisfaction married couple-seaweed farmers.

\section{PRESENTATION, ANALYSIS, AND INTERPRETATION OF DATA}

This chapter presents the data gathered, analysed, interprets and discusses the results following the sequence in the statement of the problem.

\subsection{Descriptive Data Analysis}

Table 2 presents the impact of seaweeds farming on the marital relationship satisfaction of married in terms of sex, time spent in in seaweeds farming, family income, length of marriage and family size.
It is seen in the data above, the seaweed famers has very high marital satisfaction in terms of sex, time spent in seaweeds farming, family income, years of marriage, and family size. Specifically, the family size of 5 and below with $\mathrm{M}=123.86$ and $\mathrm{SD}=17.25$ had notable result of marital satisfaction on seaweed farming. This findings is supported by the study of Valderama (2012), seaweed farming have been positive to the coastal communities. The FAO study also explains how the economic fortunes of many villages have been transformed by seaweed farming. Many of these communities routinely lived at or below poverty levels prior to engaging in aquaculture; with their incomes earned from the sale of seaweeds, many farmers have experienced substantial improvements in their standards of living as they are able to send their children to school, introduce improvements to their dwellings, enhance their diets, increase their purchasing power of material goods, etc. In particular, seaweed farming has had a remarkably positive effect on the socioeconomic status of female farmers as it allows them to engage in an income-earning activity that can be undertaken without neglecting traditional household chores.

Table 2. Impact of seaweeds farming on the marital relationship satisfaction of married in terms of sex, time spent in in seaweeds farming, family income, length of marriage and family size.

\begin{tabular}{|c|c|c|c|c|}
\hline Category & \multirow{2}{*}{$\frac{N}{76}$} & \multicolumn{2}{|c|}{ Mean SD } & \multirow[t]{2}{*}{ Description } \\
\hline A. $\quad$ Entire group & & & & \\
\hline B. Sex & & & & \\
\hline Male & 32 & 120.72 & 12.33 & Very high \\
\hline Female & 44 & 121.68 & 13.78 & Very high \\
\hline $\begin{array}{ll}\text { C. } & \text { Years of } \\
\text { marriage }\end{array}$ & & & & \\
\hline $1-15$ yrs. & 27 & 122.85 & 12.33 & Very High \\
\hline $16-30 \mathrm{yrs}$. & 32 & 120.84 & 12.40 & Very High $31-45$ \\
\hline yrs. & 17 & 119.88 & 14.09 & Very High \\
\hline \multicolumn{5}{|l|}{ D. Family size } \\
\hline 5 and below & 33 & 123.76 & 17.25 & Very high \\
\hline 6 and above & 43 & 119.26 & 12.97 & Very High \\
\hline \multirow[t]{3}{*}{$\begin{array}{ll}\text { E. Time spent } \\
\text { on seaweed } \\
\text { Farming }\end{array}$} & & & & \\
\hline & 57 & 121.86 & 12.07 & Very High 6-10 \\
\hline & 19 & 119.26 & 12.97 & Very High \\
\hline \multicolumn{5}{|l|}{ F. Family income } \\
\hline $1000-5000$ & 53 & 122.23 & 12.11 & Very High \\
\hline $6000-10000$ & 23 & 119.30 & 12.97 & Very high \\
\hline
\end{tabular}

The table 3 below on the other hand shows the difference in marital satisfaction classified according to sex. It envisaged the result showing $\mathrm{t}$-value $=0.32$ and table value $=1.993$. Based on the findings, the null hypothesis is accepted. T-value $=0.32>.05$ alpha level of significant. In particular, female or the wives' marital 
satisfaction with $\mathrm{M}=121.68$, and $\mathrm{SD}=13.78$ is greater on the other hand.

Table 3 Difference in the marital relationship in the marital relationship satisfaction classified according to sex.

\begin{tabular}{lrrrr}
\hline Category & Mean & SD & t-value & table value \\
\hline $\begin{array}{l}\text { Sex } \\
\text { Male }\end{array}$ & 120.72 & 12.33 & & \\
& & & .32 & 1.993 \\
Female & 121.68 & 13.78. & & \\
\hline
\end{tabular}

There is substantial evidence that men and women do not experience marital satisfaction in the same ways. Although satisfying marriages may benefit women in psychological and physical ways (Hess \& Saldo, 1985; Waite \& Lehrer, 2003), this gender distinction of marital satisfaction levels often corresponds with a life transition stage. On the other hand, the findings of God (2006) tells that there was difference on the marital satisfaction of two sexes. The findings suggested that a gender specific nature related to marital happiness.

The next table, Table 4 shows the difference of marital satisfaction of seaweed farmers classified according to the time spent in seaweed farming. This category had computed $\mathrm{t}$-value $=0.73$ and table value $=2.6$. The 0.05 alpha level of significant is $<$ the $t$-value $=0.73$. This means that null hypothesis is accepted.

Table 4. Difference in the marital relationship in the marital relationship satisfaction classified according to time spent in seaweeds farming.

\begin{tabular}{lrrrrr}
\hline Category & Mean & SD & t-value & table value \\
\hline $\begin{array}{l}\text { Time spent } \\
\text { 1-5 hrs. }\end{array}$ & 121.86 & 12.07 & & \\
& & & & 0.73 & 2.6 \\
6-10 hrs. & 119.26 & 13.79 & & \\
\hline
\end{tabular}

The link between spousal agreement onemployment decisions and increased marital satisfaction is also confirmed in the work by Helms et al. (2010). Findings indicated that couples who had a shared sense of family earnings and family responsibilities reported the highest levels of marital satisfaction.

Table 5 shown below elucidate marital satisfaction based on length of marriage. The computed $\mathrm{Fc}=0.32>$ .05 alpha level of significance. Thus, the null hypothesis is accepted.

Thus, on this matter, there is no significant difference on the years of marriage. In the study of Helms et al., (2010) provides insights into the marital satisfaction for dual earner couples. BY using the categories suggested by Hood (1986), they found that marital satisfaction is maximized when both spouses are co-provider perspectives that recognize the contributions of wives' employment to family earnings. Couples in co-provider group reported the greatest marital satisfaction "for whom partners' attitudes about breadwinning matched their own employment behavior and one another's attitudes."

Table 5. Difference in the marital relationship in the marital relationship satisfaction classified according to length of marriage.

\begin{tabular}{lcccc}
\hline Category & SS & df & MS & Fc \\
\hline $\begin{array}{l}\text { Years of } \\
\text { Marriage } \\
\text { Between }\end{array}$ & 105.71 & 2 & 52.86 & \\
& & & & 0.32 \\
Within & 11903.4 & 73 & 163.06 & \\
Total & 12009.11 & 75 & & \\
\hline
\end{tabular}

On the family income, table 6 shows income from 1,000-5, 000 per month has a $\mathrm{M}=122.23$ while 6,000 10,000 ha $M=119.30$. This category having a $t-$ value $=0.88>0.05$ alpha level of significance, thus the null hypothesis is accepted. There was no significant difference in the marital satisfaction of the seaweed farmers classified according to income. Li \& Fung ( 2011) companionship goals show the bonding and emotional meaningful goals that a spouse needs with the other spouse, while the instrumental goals focus on the tasks that occur throughout life that include using the spouse's physical and mental resources.

In the meantime, table 6 shows the difference in the marital relationship in the marital relationship satisfaction classified to family income. Seaweed farming is profitable venture for coastal communities (Valderama, 2012).

Table 6. Difference in the marital relationship in the marital relationship satisfaction classified according to family income.

\begin{tabular}{lll}
\hline Category & Mean & SD \\
\hline
\end{tabular}

$1,000-5,000 \quad 122.23 \quad 12.11$

$\begin{array}{lll}0.88 & 2.93\end{array}$

6,000- $10,000 \quad 119.30 \quad 13.89$

Shown in the above table, family income of 1,0005,000 has a $\mathrm{M}=122.23$ and $\mathrm{SD}=12.11$. The $\mathrm{t}$-value $=0.88$ $>0.05$ alpha level of significance. Thus, it means the null hypothesis is accepted. Anyhow, the FAO study explains how economic fortunes of many villages have been transform by seaweed farming. Many of these communities routinely lived at or below poverty levels prior to engaging in aquaculture; with their incomes earned from sale of seaweeds, many farmers have experienced substantial improvements in their standards 
of living as they are able to send their children to school, introduce improvements to their dwellings, enhance their diets, increase their purchasing power of material goods, etc. In particular, seaweed farming has had a remarkably positive effect on the socio-economic status of female farmers it allows them to engage in an income-earing activity that can be undertaken without neglecting traditional household chores.

The table 7 presents the marital relationship satisfaction according to family size. It is shown below that family size of 5 and below has a $\mathrm{M}=123.76$ and $\mathrm{SD}=$ 17.25. Meanwhile, family size of 6 and above has 119.26 and $\mathrm{SD}=12.97$. its $\mathrm{t}$-value is 1.25 and table value $=4.5$. The alpha level of 0.05 is < than the $t$-value $=1.25$. This means that the null hypothesis is accepted.

Table 7. Difference in the marital relationship in the marital relationship satisfaction classified according to family size.

\begin{tabular}{lrrrc}
\hline Category & Mean & SD & t-value & table value \\
\hline 5 and below & 123.76 & 17.25 & \\
& & & 1.25 & 4.5 \\
6 and above & 119.26 & 12.97 & & \\
\hline
\end{tabular}

That the null hypothesis is accepted. There is no significant difference in the marital satisfaction classified according to family size.

Meanwhile, te table 8 shows the reproductive roles of married couples-seaweed farmers in terms of sex, time spent in in seaweeds farming, family income, length of marriage and family size. The result shows that in terms of sex the reproductive role satisfaction is low, the same also is with family size, time spent at seaweed farming and family income. However, in the years of marriage, 15 yrs. Has moderate satisfaction on reproductive roles.

This findings is backed up in the study of Dew and Wilcox (2011) that marital satisfaction decreases in women is linked to perceived unfairness regarding housework tasks during the early child-raising years. Kawamura and Brown (2010) investigated data on 489 married women. The findings highlighted how perceptions may triumph labor division and it's on marital satisfaction. More specifically, this study revealed that to the extent to which wives perceived that they are important to their husbands, as evidenced by respect, concern, and appreciation, the more likely that are to report division of housework is fair.

Shown in the table 9, difference in the reproductive role satisfaction classified according to sex. Showing that there is a t-value $=0.31>0.05$ alpha level of significance. This means that the null hypothesis is accepted. Thus, there is no significant difference in the reproductive satisfaction of both sexes. This is however contrary to the findings Twenge et al (2003) linked a decline in marital satisfaction for married women to increased role restriction after entering into motherhood. Research has suggested that wives are happier with their husbands (Amato et al., 2003). In a marital satisfaction study examining parenting couples, Meier, McNaughtonCassil, and Lynch (2006) found that women were more satisfied with their marriage if household and parenting tasks were seen as shared endeavor.

Table 8. Impact of seaweeds farming on the reproductive roles of married couples in terms of sex, time spent in in seaweeds farming, family income, length of marriage and family size.

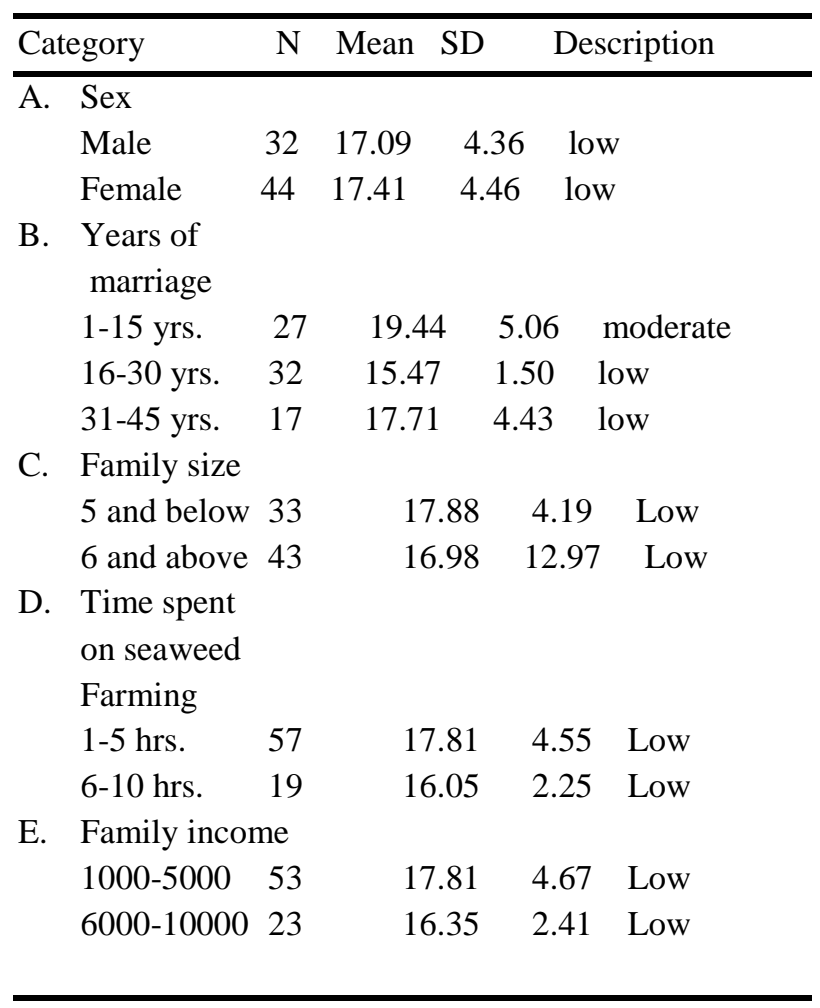

Table 9. Difference in the reproductive role satisfaction classified according to sex.

\begin{tabular}{|c|c|c|c|c|}
\hline Category & Mean & SD & t-value & table value \\
\hline Male & 17.09 & 4.36 & \multirow{3}{*}{0.31} & \multirow{3}{*}{1.993} \\
\hline & & & & \\
\hline Female & 17.41 & 4.46 & & \\
\hline
\end{tabular}

Meanwhile, table 10 shows reproductive role satisfaction classified according to time spent in seaweeds farming. The time $1-5$ hrs. has a $M=17.81$ and $\mathrm{SD}=4.55$. While the $6-10 \mathrm{hrs}$. time spent has $\mathrm{M}=16.05$ and $\mathrm{SD}=2.25$. The $\mathrm{t}-\mathrm{value}=3.48>0.05$ alpha level of significant difference. Thus, this means that the null hypothesis is accepted.

In marriages with traditional roles, a husband retains a head of the family position that varies in degree and 
kind in each specific marriage. Family life (finances, decision-making) and household tasks are typically performed along gender lines (wives cook; husbands take care of the yard) in traditional marriages.

Table 10. Difference in the reproductive role satisfaction classified according to time spent in seaweeds farming.

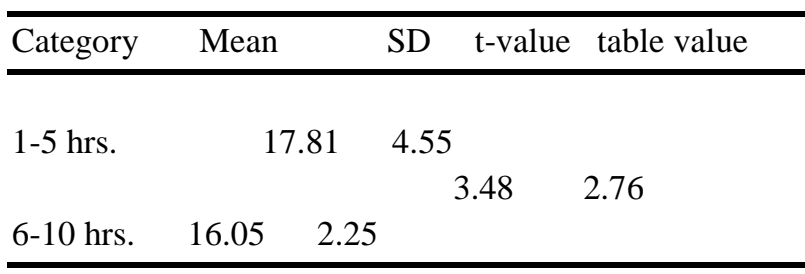

Table 11. Difference in the reproductive role satisfaction classified according to family income in seaweeds farming.

\begin{tabular}{lllll}
\hline Category & Mean & SD & t-value & table value \\
\hline $1,000-5,000$ & 17.81 & 4.67 & & \\
$6,000-10,000$ & 16.35 & 2.41 & & 1.79 \\
\hline
\end{tabular}

As shown above, the Table 11 discusses the difference in the reproductive role satisfaction classified according to family income. The t-value $=1.79$ and table value $=1.46$. The $t$-value $=1.79>0.05$ alpha level of significant difference. So on this findings, null hypothesis is accepted. Some studies suggest that decision to be a single earner or dual household closely intersects with couples' beliefs related to gender roles. Shared spousal views of traditional gender roles has been seen as a significant indicator of higher levels of marital satisfaction in some studies (Greenstein, 1995; Livingston, Burley, and Springer, 1996; Zvonkovic, Schmiege, \& Hall, 1994; Caudill, 2012). Yet there is evidence of a constraining relationship in other research findings (McCreary et al., 1996; Olson, Fye, \& Olson, 1999; Caudill, 2012).

Table 12. Difference in the reproductive role satisfaction classified according to years of marriage.

\begin{tabular}{lrrrr}
\hline Source of Variation & SS & df & MS & Fc \\
\hline Between group & 233.77 & 2 & 116.89 & \\
& & & & 8.14 \\
Within group & 1048.16 & 73 & 14.36 & \\
Total & 1281.93 & 75 & & \\
\hline
\end{tabular}

On this table 12 , the difference in the reproductive role satisfaction classified according to years of marriage. The $\mathrm{Fc}=8.14>$ alpha level of significant difference. Therefor the null hypothesis is accepted. This is no significant difference in the reproductive role satisfaction when classified according to years of marriage.
Husbands' and wives' continue to form marriage relationships that involve dual employment (Helms et al., 2010.

Finally, on table 13 difference in the reproductive role satisfaction classified according to family size is shown. The category 5 and below had $\mathrm{M}=17.88, \mathrm{SD}=4.19$ and category 6 and above had $\mathrm{M}=16.98, \mathrm{SD}=12.97$. The $\mathrm{t}$ value $=0.9>$ alpha level of significant difference, thus the null hypothesis is accepted. Which means there is no significant in the reproductive role satisfaction classified according to family size.

Table 13. Difference in the reproductive role satisfaction classified according to family size.

\begin{tabular}{lclcc}
\hline Category & Mean & SD & t-value & value table \\
\hline 5 and below & 17.88 & 4.19 & & \\
& & & 0.9 & 0.43 \\
6 and above & 16.98 & 12.97 & & \\
\hline
\end{tabular}

\section{SUMMARY OF FINDINGS, CONCLUSION AND RECOMMENDATION}

This chapter presents the summary of findings, conclusion, and recommendations. Summary of findings presents brief presentation of the results of the study. Meanwhile, the conclusion drawn were taken from the findings of the study. Recommendations were proposed for the improvement of the study in the relevant areas.

\subsection{Summary of Findings}

Marital satisfaction is vital to each spouses. This can be one determining factors of a happy and lasting family life. Reproductive role satisfaction is at same time makes a healthier family bond. The married couple-seaweed farmers have very high marital satisfaction in terms of sex, time spent in seaweeds farming, family income, years of marriage, and family size. Specifically, the family size of 5 and below with $M=123.86$ and $S D=17.25$ had notable result of marital satisfaction as seaweed farmers. Meanwhile, on determining the significant difference on marital satisfaction in terms of sex, it envisaged the result showing $\mathrm{t}$-value $=0.32$ and table value $=1.993$. Based on the findings the null hypothesis is accepted. In terms of time spent in seaweed farming. This category had computed $\mathrm{t}$-value $=0.73$ and table value $=2.6$. The 0.05 alpha level of significant is $<$ the $t-$ value $=0.73$. This means that null hypothesis is accepted.

Moreover, difference on marital satisfaction based on length of marriage. The computed $\mathrm{Fc}=0.32>.05$ alpha level of significance. Thus, the null hypothesis is accepted. There is no significant difference on the years of marriage. Same with marital satisfaction of the seaweed farmers classified according to income. There was no significant difference. 
In the meantime, family income the $\mathrm{t}$-value $=0.88>$ 0.05 alpha level of significance. Thus, it means the null hypothesis is accepted. Likewise, there is no significant difference in the marital satisfaction classified according to family size.

On the aspect of reproductive role, study have revealed that married couples-seaweed farmers in terms of sex the reproductive role satisfaction is low, the same also is with family size, time spent at seaweed farming and family income. However, in the years of marriage, 15 yrs. Has moderate satisfaction on reproductive roles.

In particular, this study revealed that to the extent to which wives perceived that they are important to their husbands, as evidenced by respect, concern, and appreciation, the more likely that are to report division of housework is fair.

On the other hand, study exhibited no the significant difference on reproductive role satisfaction in terms of sex. There was the same reproductive satisfaction of both sexes. On time spent in seaweeds farming. There was no significant difference whether how long they spend in seaweed farming. It did not affect the reproductive role satisfaction.

In terms on family income, the t-value $=1.79>0.05$ alpha level of significant difference. There was no significant difference in the family income as to their reproductive role.

Same through, this is no significant difference in the reproductive role satisfaction when classified according to years of marriage.

Finally, reproductive role satisfaction classified according to family size the $\mathrm{t}$-value $=0.9>$ alpha level of significant difference which means there is no significant in the reproductive role satisfaction classified according to family size.

\section{CONCLUSION}

Seaweed farming in Brgy. Tiabas, San Dionesio plays a significant role in the lives of the residents. It also contributed to the marital relationship among couples who are relying their staple food from the produce of seaweed farming.

Seaweed farming has had a remarkably positive effect on the socioeconomic status of female farmers as it allows them to engage in an income-earning activity that can be undertaken without neglecting traditional household chores.

Moreover, couples who had a shared sense of family earnings and family responsibilities reported the highest levels of marital satisfaction.

\section{RECOMMENDATION}

Based on the findings of the study and conclusions drawn, the following are the recommendations for the improvement of the study:

To the married couples who are engaging in any livelihood, shared responsibility on income generating and reproductive role should be considered to achieve marital satisfaction.

Along with the above recommendation, capability building, personality development, smart parenting, gender and development related topics and the likes should be given to the community, especially to the married couple-seaweed farmers of Brgy. Tiabas, San Dionesio are highly recommended.

It is suggested to the LGU of San Dionesio, Iloilo, Philippines to open more assistance to seaweed farming in the form of financial and other social supports to flourish the seaweed farming industry and uplift the living condition of the community. Since as seen in the results of this study, seaweed farming play significance in the marital and reproductive roles of every spouses.

To the future researchers who are attracted on this kind of studies a study on the well-being of seaweed farmers could be a great avenue for new knowledge.

\section{REFERENCES}

[1] Beach, S. R. H., Martin, J. K., Blum, T. C., \& Roman, P. M. (1993). The effects of marital and coworker relationships on negative affect: Testing the central role of marriage. The American Journal of Family Therapy, 21(4), 313-323.

[2] Blau, P.M. (1964). Social exchange theory. Retrieved from: https://scholar.google.com.ph/scholar?hl=en\&as_s $\mathrm{dt}=0 \% 2$ C5\&as_vis $=1 \& \mathrm{q}=\mathrm{blau}+1964+$ social + exch $\underline{\text { ange }+ \text { theory } \& \text { oq }=\text { Blau }+1964}$

[3] Cherlin, A.J. (2005). American marriage in the early twenty-first century. Retrieved from: https://scholar.google.com.ph/scholar?hl=en\&as_s $\mathrm{dt}=0 \% 2 \mathrm{C} \&$ as_vis $=1 \& \mathrm{qcherlin}+2005+$ american $+\mathrm{m}$ arriage $\&$ oq $=\mathrm{Cherlin} \% 2 \mathrm{C}+2005$

[4] Derogatis, L. R., \& Melisaratos, N. (1983). The Brief Symptom Inventory: An introductory report. Psychological Medicine, 13, 595-605.

[5] Helms, H.M \& Walls, JK (2010). Provider role

[6] attitudes, marital satisfaction, role overload, and housework: A dyadic approach. Retrieved from: https://scholar.google.com.ph/scholar?hl=en\&as_s $\mathrm{dt}=0 \% 2 \mathrm{C} 5 \&$ as_vis $=1 \& \mathrm{q}=$ helms $+2010+$ satisfactio $\mathrm{n} \& \mathrm{oq}=$ Helms +2010 
[7] Faulkner, R. A., Davey, M., \& Davey, A. (2005). Gender-related predictors of change in marital satisfaction and marital conflict. The American Journal of Family Therapy, 33, 61-83.

[8] Fung, H \& Li, T. (2011). The Dynamic Goal Theory of Marital Satisfaction. Retrieve from: https://journals.sagepub.com/doi/abs/10.1037/a002 $\underline{4694}$

[9] Hurtado, FC (2013). Genome structure and metabolic features in the red seaweed Chondrus crispus shed light on evolution of the Archaeplastida. Retrieved from: https://www.pnas.org/content/110/13/5247.short

[10] Lynch, M \& M McNaughton C Cassil (2006). The management of the household and childcare tasks and relationship satisfaction in dual-earner families. Retrieved from: https://scholar.goople.com.ph/scholar?q=lynch+20 06+impact+of+marital+satisfaction \&hl=en\&as_sdt $=0 \&$ as_vis $=\&$ oi $=$ scholart

[11] National Institute of Mental Health. (2007). Men and depression. Retrieved Oct. 25, 2007, from http://www.nimh.nih.gov/publicat/index.cfm.

[12] McElwin, A. (2005). Extending the demandscontrol model: a daily diary study of job characteristics, work-family conflict and workfamily facilitation. Retrieved from: https://scholar.google.com.ph/scholar?hl=en\&as_s $\underline{\mathrm{dt}=0 \% 2 \mathrm{C} 5 \& \mathrm{as} \text { vis }=1 \& \mathrm{q}=\mathrm{McElwain}+2005+\text { gender }}$ + role+ideology\&btnG $=$

[13] Renne, K. S. (1970). Correlates of dissatisfaction in marriage. Journal of Marriage and the Family, 32(1), 54-67.
[14] Ross, C. (1991). Marriage and sense of control. Journal of Marriage and the Family, 53(4), 831838.

[15] Schumm, W. R., Paff-Bergen, L. A., Hatch, R. C., Obiorah, F. C., Copeland, J. M., Meens, L. D., \& Bugaighis, M. A. (1986). Concurrent and discriminant validity of the Kansas Marital Satisfaction Scale. Journal of Marriage and the Family, 48(2), 381-387.

[16] Spanier, G. B. (1976). Measuring dyadic adjustment: New scales for assessing quality of marriage and similar dyads. Journal of Marriage and the Family, 38(1), 15-28.

[17] Sokloski, D.M. (1995). A study of marital satisfaction in graduate student marriages. Retrieved from: https://scholar.google.com.ph/scholar?hl=en\&as_s $\mathrm{dt}=0 \% 2 C 5 \&$ as_vis $=1 \& \mathrm{q}=$ Sokolski+1995+marital+ satisfaction $+\& b \operatorname{tnG}=$

[18] Valderama, D. (2012). Social and economic dimensions of seaweed farming: a global review. Retrieved from https://www.google.com/search?q=Valderama\%2 $\mathrm{C}+2012+$ sea+weed\&rlz=1C1RUCY enPH854PH 858\&oq=Valderama\%2C $+2012 \&$ aqs $=$ chrome .1 .69 i57j69i59.1979j0j8\&sourceid $=$ chrome $\&$

[19] Vogel, D. L., Wester, S. R., Heesacker, M., \& Madon, S. (2003). Confirming gender stereotypes: A social role perspective. Sex Roles, 48(11/12), 519-528.

[20] Williams, K. (2003). Has the future of marriage arrived? A contemporary examination of gender, marriage, and psychological well-being. Journal of Health and Social Behavior, 44, 470-487. 